\title{
Multimodal features of assessment in Indonesian conversation: A conversation analysis study
}

\author{
Kadek Ratih Dwi Oktarini \\ School of Humanities, College of Humanities and Social Sciences, Nanyang Technological University, 50 \\ Nanyang Avenue, 639798, Singapore
}

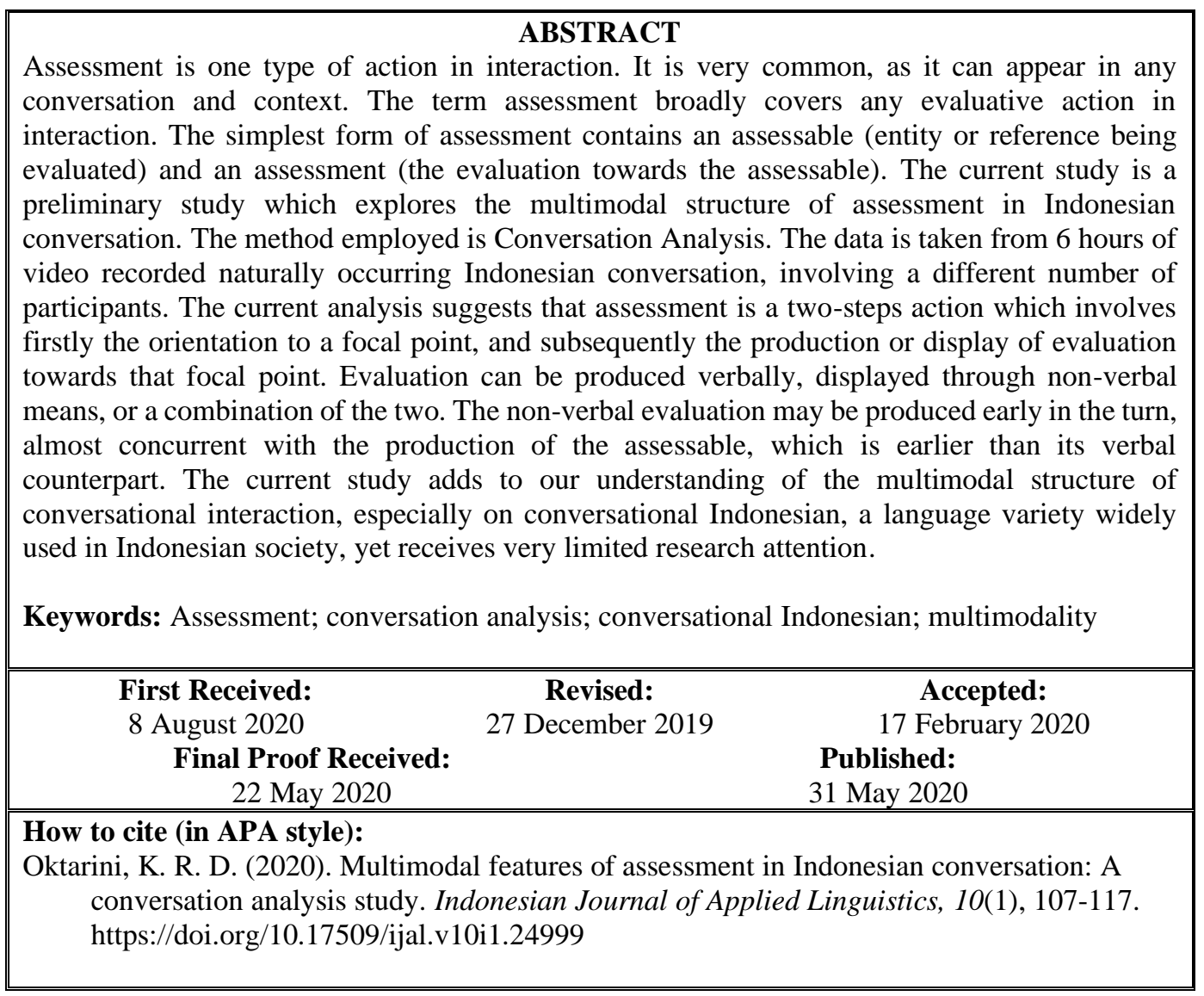

\section{INTRODUCTION}

Assessment is one type of action in interaction. Other types of action in interaction are such as request, offer, invitation, complaint, etc. Assessment is very common since it broadly covers various types of evaluative action. It occurs in various contexts, such as pedagogy (Pillet-Shore, 2012), medical (Antaki \& O'Reilly, 2013), adult-child interaction (Filipi \& Wales, 2010), etc. It can be done towards various types of objects, such as people, items, ideas, activity, etc.

In terms of structure, in general, assessment consists of two elements: assessable (referent) and assessment/ assessment term/ evaluation. Assessable or referent is the object of the assessment or evaluation. Assessment, assessment term, or evaluation is the element of the talk that carries the assessment or evaluation. Assessment or evaluation may be carried through different modalities, and not only verbal/ linguistic means (e.g. Goodwin, 1986; Goodwin \& Goodwin, 1987; Goodwin, 2007; Ruusuvuori \& Peräkylä, 2009).

Assessment may occur as a single (conversational) turn, containing an assessable and an assessment term (e.g. Extract 1). Assessment may also occur in bits and pieces through multiple (conversational) turns, performed by multiple participants (e.g. Extract 2). 
Extract 1: Single-turn assessment ( Pomerantz, 1984, p. 60)

1 A : $\quad$... She was a nice lady

Extract 2: multi-turn, multi-participants assessment ( Pomerantz, 1984, p. 57)

$1 \mathrm{~J}: \quad$ Let's feel the water. Oh it..

$2 \mathrm{R}: \quad$ It's wonderful. It's just right. It's like

Bathtub water

In Extract 1, the assessment is produced as a single (conversational) turn (Line 1) and by a single speaker (Speaker A). While in Extract 2, the assessment spanned two (conversational) turns by two speakers ( $\mathrm{J}$ and $\mathrm{R}$ ). In Line $1, \mathrm{~J}$ produces the assessable 'the water', while inviting $\mathrm{R}$ to feel the water. The assessment is then produced by $R$ afterward, i.e. 'wonderful'.

Perhaps owing to its ubiquity and straightforward nature of identification in conversational data, to date, there is a quite sizeable study on assessment (such as Filipi \& Wales, 2010; Goodwin, 1986; Jones, 1997; Pomerantz, 1975; Takanashi et al., 2006; Tanaka, 2016; Tolins, 2013, etc.). Those studies are either focusing on the assessment itself or utilizing assessment as a point of departure to study other interactional phenomena.

One of the earliest works on assessment by Pomerantz (1984) has given way for the observation of a fundamental structure in social interaction, namely preference organization (Pomerantz \& Heritage, 2013). The same study (Pomerantz, 1984) has also given a solid foundation for the investigation of some key topics in Conversation Analysis (CA), such as affiliation (Lindstrom \& Sorjonen, 2013) and response design (Lee, 2013). Slightly later works on assessment, such as Goodwin (1986), and Goodwin and Goodwin (1987) contribute greatly to the development of interest on the multimodal structure of social interaction. Epistemic in interaction, one of the key topics in CA, has also begun to be investigated through the investigation of assessment (Heritage, 2012; Heritage \& Raymond, 2005; Raymond \& Heritage, 2006).

Though assessment has been productively studied before, up to this point in time, it is still a relevant topic. In the year 2018 alone, there are at least 7 published works on assessment. Two of them focus on the structure of assessment itself (Park, 2018; Seuren, 2018); while, five other employ assessment as starting point to analyze other interactional phenomena (Benwell \& Rhys, 2018; Day \& Kristiansen, 2018; Ivaldi, 2018; Kiyimba et al., 2018; Oshima, 2018). The current study focuses on the structure of assessment itself in Indonesian conversation. It is a less explored topic, in a less explored language (conversational Indonesian).

So far, to the best of my knowledge, there has been no highly accessible journal article on assessment in Indonesian (Language). This is rather surprising and disappointing, considering that it has been a while since the initial works on assessment (the late 70s and early 80s) and there have been numerous works on assessment. A quick search on
Ethnomethodology and Conversation Analysis bibliography database (EMCA Bibliography Database, n.d.) results in 138 entries for keyword "assessment", which means that to date, there are roughly 138 works on assessment.

Perhaps, the issue scarcity is not limited to the study on assessment per se, it may well be a common problem in the field of research on Conversational Indonesia.

The term "Indonesian Language" encompasses wide varieties of regional and formality level. Different regions in Indonesian may have their own "local flavor" or "variety". Some varieties that have been documented are Riau (Gil, 2008), Papua (Fields \& Fields, 2010), Manado (Stoel, 2000), Jakarta (Sneddon, 2006), etc. In addition, owing to its diglossic situation (Sneddon, 2003), less attention has been given to conversational Indonesian, as opposed to its highly celebrated and standardized counterpart: the standard Indonesian. Though the conversational and standard Indonesian share a high number of common vocabularies, conversational Indonesian varieties are generally less complex than standard Indonesian, especially in terms of verbal morphology (See Ewing, 2005 for a more detailed discussion on the structure of conversational Indonesian ).

Though most Indonesian speak conversation/ colloquial Indonesian (Ewing, 2005), it appears that there is a strong tendency of denying its legitimacy. A similar tendency appears to be present in research on Conversational Indonesian. Studies that investigate naturally occurring conversational Indonesian are very scarce or simply hard to access. To date and to the best of my knowledge, there are only a handful of highly accessible works on conversational/ colloquial Indonesian. Some of the highly accessed works are Sneddon (2006), Wouk (1998; 2001, 2005), Williams (2009), Ewing (2005), Djenar (2006; 2013), and Djenar \& Ewing (2015).

The current study is aimed at filling the gap in the field of research of conversational Indonesian, specifically on naturally occurring face to face conversational Indonesian. As a preliminary study, the current study is intended to be a foundation of further studies on naturally occurring Indonesian/ conversational Indonesian.

\section{METHOD}

The current study employed the qualitative approach of Conversation Analysis (CA). CA is initially built upon the observation that people take turn to talk (Sacks et al., 1974). Different than the conventional linguistics units of sentence, clause, phrase, and 
word: the fundamental unit of CA is (conversational) turn. Turn is marked by the changing of speaker. A turn may be made up of different units. Those units are referred to as Turn Constructional Unit (TCU): a unit of talk that is capable of being understood in solitary. A TCU may consist of linguistic or nonlinguistic item. It may consist of a single facial movement, facial expression, gesticulation, phrase, clause, or even sentence.

\section{Data and participants}

The current study employed some 6-hours of videorecorded, naturally-occurring Indonesian conversation. Naturally occurring conversation refers to the non-directed conversation. The participants are given the freedom to talk about any topic in any way they want. The point is to record and analyze authentic interaction.

The recording was done some years ago in Bali, Indonesia. Provisionally the language variety in the recording can be referred to as "conversational Indonesian spoken in Bali" (Oktarini, 2017, p. 8) to recognize some elements of the data and findings which may not be readily applicable to other regional varieties of Indonesian.

There are 25 participants in the video recording. All of the participants are above 18 years old and have given their written consent to participate in the study. Pseudonyms and mock place names are in use to maintain the participant's anonymity. Sketches, generated from tracing the still images from the video recording, are also in use when required to maintain the participant's anonymity.

\section{Data analysis}

The first step in doing a study employing Conversation Analysis is to create a "collection" (ten Have, 2007; Sidnell, 2010). In the current study, that first step is creating an assessment collection (collection of excerpts containing assessments). There is roughly 190 sequence of assessment or sequence of interaction containing assessment (extracts) in the 6 hours data. Some consist of a single turn containing/ performing assessment, while some may consist of even up to ten assessments.

After creating an assessment collection, a careful and fine-grained multimodal analysis on each of the assessments in the collection is done.
For the current study, the term "verbal modality" of assessment refers to any evaluative action done through verbal means. While the term "non-verbal modality" of assessment refers to any evaluative action involving bodily movements or facial expressions. CA studies has long identified bodily movement as a modality or mean to perform communicative action (see Goodwin \& Goodwin, 1987; Goodwin, 2007; Kaukomaa et al., 2013; Schenkein, 1978, etc.).

Fasulo and Monzoni (2009) even employ the term "assessment" to refer to the multimodal act of assessment, while employing the term "verbal assessment" to refer to an assessment done verbally. Their classification points out to the understanding of the significance of multimodality in the construction of assessment. Assessment is essentially multimodal.

The Findings and Discussion section of this article present the result of the multimodal analysis of the collection.

\section{FINDINGS AND DISCUSSION}

The current study observes some of the basic features of (multimodal) assessment in the Indonesian Language. The findings and discussion sections are divided into three main sub-sections. It starts with the simplest kind of assessment, assessment produced by one participant as one turn. Then the section continues with the more complex kind of assessment, assessment jointly produced by two participants. The section then ends with an even more complex assessment, assessment produced by more than two participants.

\section{Assessment produced by one participant as one turn}

This sub-section presents two conversational extracts: the first one is a verbal assessment and the second one is a combination of verbal and non-verbal assessment.

\section{Verbal assessment}

In Extract 3 below, Putri is talking to Gede about one of the rides that she tried in Taman Ria, an amusement park that she visited a few months ago.

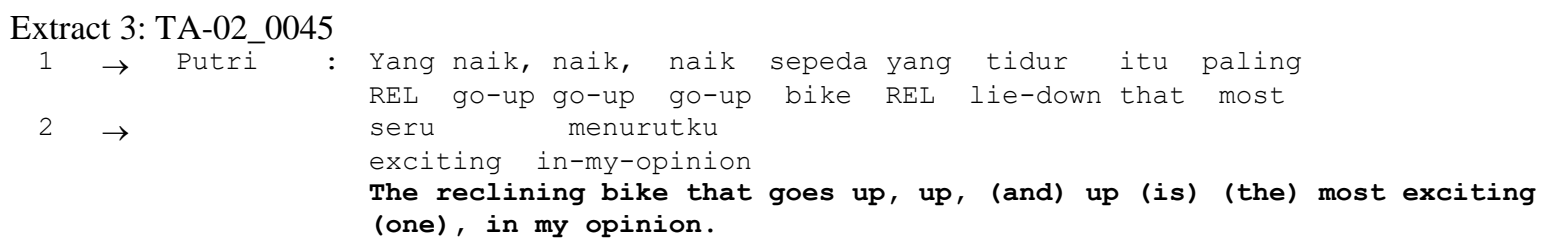

In Extract 3, Putri says, yang naik, naik, naik sepeda yang tidur itu yang paling seru menurutku 'the reclining bike that goes up, up, (and) up (is) (the) most exciting (one), in my opinion' (Line 1-2). The assessable is yang naik, naik, naik sepeda yang tidur itu 'the reclining bike that goes up, up, (and) up' (Line 1). While the (verbal) assessment term is paling seru '(the) most exciting' (Line 1-2).

The assessment in Line 1-2, Extract 3 is produced within a part of a conversation on different 
rides that Putri tried in an amusement park she visited a few months ago. In all likelihood, Gede, the listener, has not ridden that ride or even visited that amusement park. He is only planning to visit the city where the amusement park is located.

Putri produces the assessable in Extract 3 (Line 1) little by little, letting Gede slowly imagine and figure out the assessable. By that, Gede orients his attention to the ride, though he has not seen it before. After producing the assessable in such a way (Line 1), Putri produces the assessment, i.e. paling seru '(the) most exciting' (Line 1-2).

The organization of Putri's assessment in Extract 3 (Line 1-2) points out that, firstly, assessment is a two-step action. The first step is to get the hearer or the interlocutor to orient (direct his or her attention) to a focal point. The second step is to produce their assessment towards that entity that has just been established as a focal point. In Extract 3, the orientation to a focal point (presentation of assessable) precedes the presentation of assessment.

The bulk of current literature on assessment focuses on the evaluative element of assessment (such as Antaki, 2002; Goodwin \& Goodwin, 1992; Ivaldi, 2018, etc.) or response to assessment (such as Hayano, 2011; Heritage, 2002; Pomerantz, 1975, etc.). So far, almost no attention is given to the structure of presenting the assessable. As we observed in Extract 3, in establishing orientation to the assessable is crucial in assessment (Cf. Oktarini, 2019). Participants' orientation to the assessable needs to be established prior to the production of assessment or evaluation of the assessable.

The above ordering also in line with Indonesian grammatical structure, in which Noun (subject) is produced before Adjective (predicate). Different ordering is observed in language that has non-Noun initial grammatical structures, such as Japanese (Tanaka, 2016).

\section{Verbal and non-verbal assessment}

Extract 4 occurs in a five-party conversation: Ms K and her four former students: Ketut, Made, Rani, Rina, and Wayan.

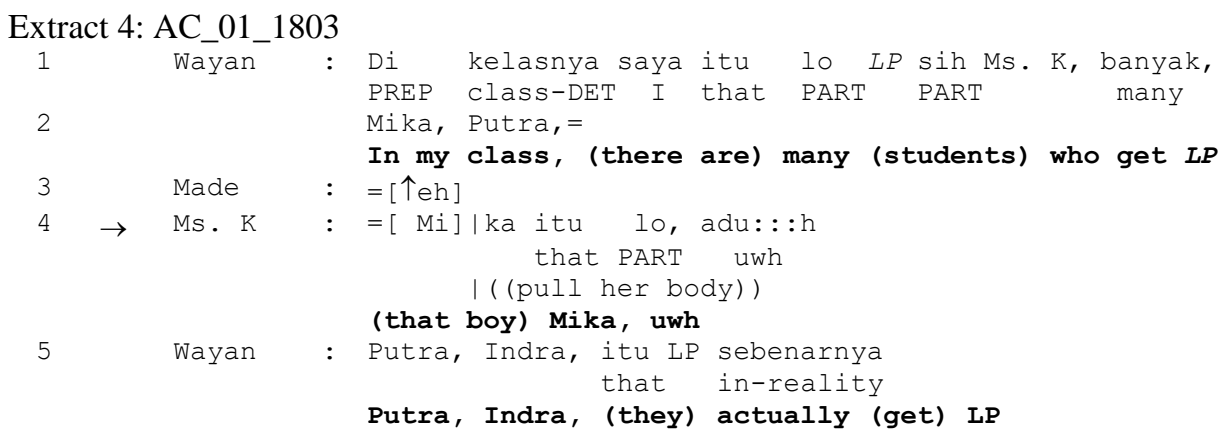

$L P$ in Line 2 Extract 4 stands for Lulus Percobaan 'probationary pass'. In line 1 Wayan tells Ms $\mathrm{K}$ that there are many students who get $L P$ on the previous semester. She then continues by listing down the students, Mika, Putra, (Line 2).

However, before Wayan completes listing the students down, both Made and Ms K produce a turn. Made produces an interjection, a rising intonation $\mathrm{eh}$. The rising intonation $e h$, indicates disbelief. While, Ms K produces a turn, Mika itu lo, adu::h '(that boy) Mika, uwh' (Line 4).

Figure 1 depicts the moment when Ms K initiates Line 4 , at the point when she produces the syllable $M i$ - (see Extract 4, Line 4). Figure 2 depicts the moment shortly after when Ms $\mathrm{K}$ produces the syllable - $k a$ of the word Mika (Extract 4, Line 4). By comparing the two still images (sketches), Ms K's bodily movement is clearly observable. Ms $\mathrm{K}$ is the one who sits with her back to the camera. In Figure 1 , we can observe that Ms K's is sitting in a straight posture. Then, in Figure 2, we can observe how Ms $\mathrm{K}$ pulls her body backward and tilts her head to the left.

Ms K's turn (Line 4) is an assessment. The assessable is Mika. The evaluation or assessment is done through non-verbal and verbal modalities. The non-verbal modality is Ms K's bodily movement. Her bodily movement can be understood as a kind display of frustration. While the verbal modality is interjection aduh 'uwh' (Line 4).

Aduh 'uwh', an Indonesian interjection, is commonly produced in the presence of some kind of misfortune or other negative circumstances. Aduh can be produced in the context of frustration as well.

In Line 4, aduh 'uwh' is produced in an elongated way, and there is discernible stress on the second syllable duh. The elongation and stress intensify the conveyance of the word $a d u h$. Together, the two modalities can be understood as revealing Ms K's frustration or her negative assessment towards the assessable.

The piece of conversation in Extract 4 shows that, firstly, assessment can be produced through both verbal and non-verbal modalities. Then secondly, assessment can be carried by verbal means other than an adjective, i.e. interjection. Thirdly, non-verbal assessment can be performed rather early, i.e. in overlap with the tail end of the production of the assessable. 
Figure 1

Ms K's body position at the beginning of Line 4 (Extract 4)

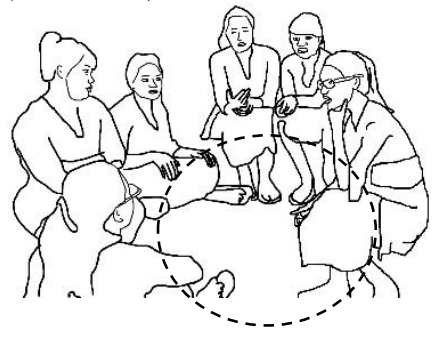

The observation in Extract 4 holds the stipulated principle that assessment is a two-step action: first is getting the hearer to orient to a focal point and second is producing the assessment.

In Extract 4, the speaker orients the listener to a focal point by mentioning the name Mika. Earlier, in Line 2, two names are being mentioned. Through the mention of Mika at the beginning of Line 4, attention is brought towards Mika, instead of the other name, i.e. Putra.

Another principle that can be proposed based on the observation in Extract 4 is regarding the organization of non-verbal and verbal assessment in the case where both are present. Non-verbal assessment can "leak" and be produced almost concurrently with the assessable. The non-verbal assessment is not done in complete overlap with the production of the assessable in Extract 4.
Figure 2

Ms K's body position at the second syllable of Line 4 (Extract 4)

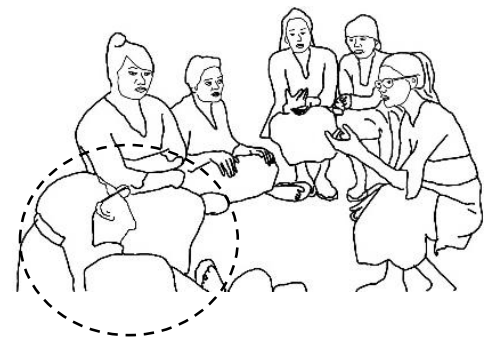

Earlier literature on assessment (Goodwin \& Goodwin, 1992) has touched upon the problem of delineating assessment. Evaluation can be produced non-verbally and is concurrent with other verbal actions. Our finding in Extract 4 adds more granularity to Goodwin and Goodwin (1992) claim. Non-verbal evaluation can be performed prior to its verbal counterpart and even almost overlap with the assessable.

Assessment jointly produced by two participants First speaker produces assessable, second speaker produces assessment

Extract 5 occurs in a two-party conversation. Gede is going to visit a city (T) that Putri has just visited a few months back. Gede mentions the name of some places, and then Putri gives her opinion about whether those places are worth to visit.

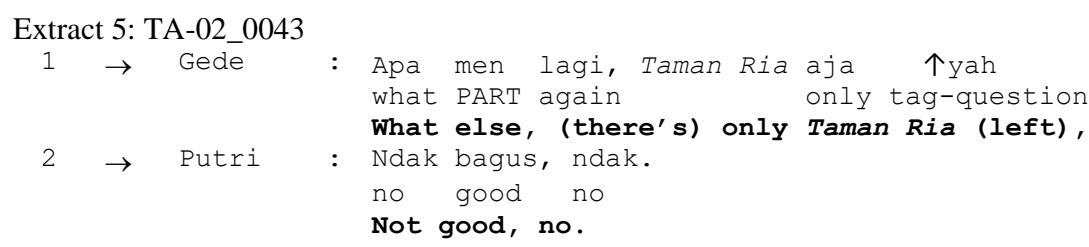

In Line 1 Gede mentions Taman Ria, referring to a famous amusement park in $\mathrm{T}$ City while indicating that Taman Ria may be the last thing on his mind (Line 1). Without leaving a considerable gap in between, Putri says, ndak bagus, ndak 'not good, no', indicating that Taman Ria is not a good place to visit.

In this extract (Extract 5), the assessment (action) is produced jointly by the two participants, Gede and Putri. In Line 1, Gede produces the assessable, Taman Ria. Then, in Line 2 Putri produces the assessment.

The observation in Extract 5 points out to firstly the participants' orientation to the ongoing project (Cf. Levinson, 2013). The participants are aware that the project of this particular part of the conversation is sharing evaluation on places. Hence, when Gede proposes a name, Putri immediately can produce an evaluation. Secondly, the observation in Extract 5 also points out to the participants' orientation to the structure of assessment in grammatical sense (Ochs et al., 1996), much like how the participant can cooperatively construct an if-clause (Lerner, 1996).

\section{First speaker produces assessable and assessment after being prompted by second speaker}

Extract 6 occurs a few seconds after the talk in Extract 5. The participants, Gede and Putri, are still talking about Taman Ria, the amusement park discussed in Extract 5. In Extract 6, Putri shares her opinion after trying out (all) rides in Taman Ria.

In Line 1-2 (Extract 6) Putri says, semua wahana, semua semua semua tuh bisa make. Tak cobain tuh, satu- semuanya tak cobain '(I) can ride all, all, all rides; (and) I tried that, one-, I tried them all'. She mentions about all rides (in Taman Ria), while also informing that she has tried them all.

There is a cut-off quality at the end of the word satu 'one' (Line 2). The cut-off may be an indication of a self-repair (Schegloff, 2007, 2013). She may have planned to say tak cobain tuh, satu - satu 'I tried one by one', putting emphasizing on how she has 
tried each of the rides. However, she changes her turn midway into semuanya tak cobain 'I tried them all', emphasizing on her comprehensive experience regarding the rides in Taman Ria.

In Line 3, Gede says trus '(and) then' in a rising intonation. His turn can be understood as a request for Putri to continue her turn. The talk in Extract 6 can be said to be produced within a bigger "project" (Levinson, 2013) of getting Putri's recommendation regarding places to visit in T City. By asking Putri to continue, Gede orients to that bigger project, ushering Putri to continue with her assessment regarding the rides.

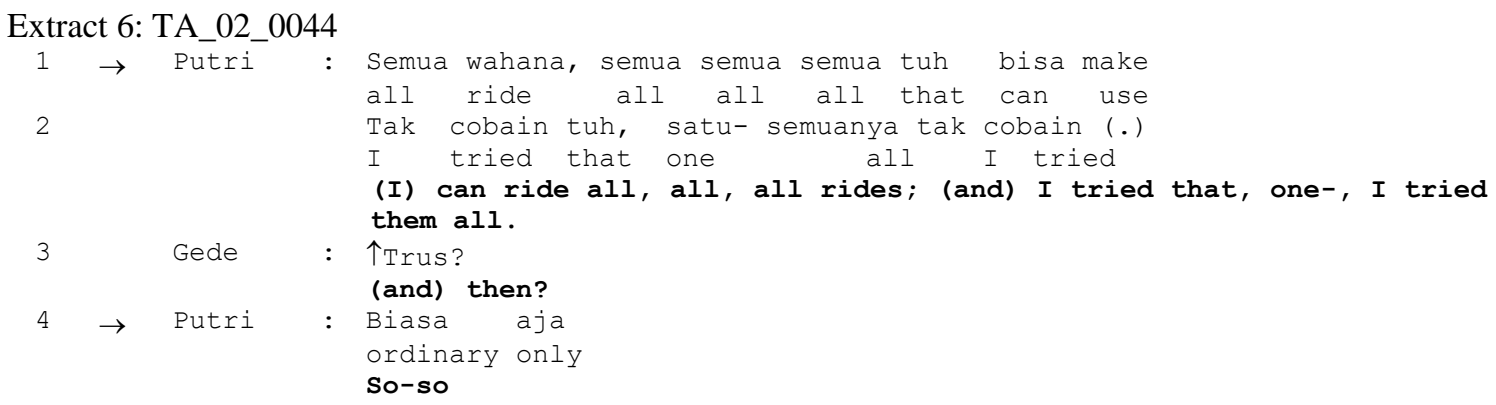

As prompted by Gede, Putri then produces her assessment regarding all rides in Taman Ria (Line 4). She says biasa aja 'so-so'. In so doing, Line 1-2 which was initially produced as an informing is then turned into the first part of an assessment, with Line 4 as its second part.

Similar to the assessment in Extract 5, the assessment in Extract 6 is jointly produced. The difference is, in Extract 5 the assessable and assessment term is produced by different participants; while in Extract 6, the assessable and assessment term is produced by the same participant. Instead of producing the assessment, in Extract 6, the second participant prompts the first participant to produce the assessment term.

The observation in Extract 6 points out to the participants' orientation to their epistemic status
(Heritage, 2012; Heritage \& Raymond, 2005; Raymond \& Heritage, 2006), as well as the current interactional project and interactional grammatical structure. Gede who has no knowledge about the rides understands that as an assessment, the action is incomplete. However, he cannot complete the action by himself as he does not have the knowledge to produce the evaluation. Hence, he prompts Putri to produce the assessment.

Assessment jointly produced by more than two participants

First speaker produces assessable and assessment after prompted by another speaker

Extract 7 is an all-female, 4-party, conversation (Ayu, Dewi, Santi, and Eka). However, since Eka is occupied with her phone, she does not contribute to the conversation.

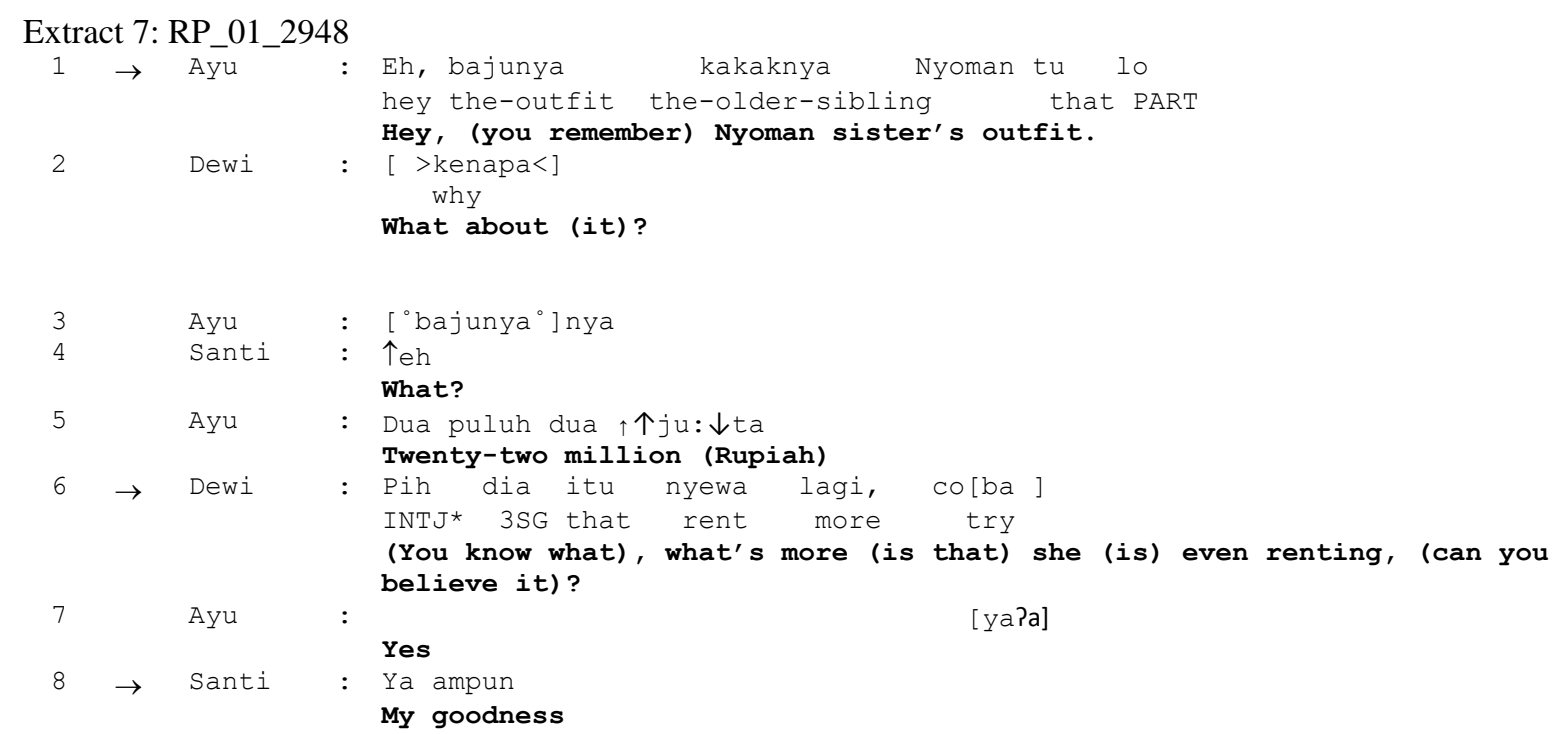

In Line 1 Ayu says, eh, bajunya kakaknya Nyoman tu lo 'hey (you remember) Nyoman sister's outfit'. Kakaknya Nyoman is translated as 'Nyoman's sister' (Line 1). Earlier, the participants talk about their experience in attending Nyoman sister's wedding. Though Ayu employs gender-neutral pronoun kakak 'older sibling', from that earlier talk, we know that Nyoman's older sibling is a female.

Indonesian demonstrative pronoun $t u$ 'that' refers to a remote object. It may be remote in terms 
of location or time. Since the reference is nondiscoverable in the physical surrounding, likely, $t u$ refers to a remote object in the time dimension. It refers to an object from the past. $T u$ 'that' (Line 1) can be understood as referring to the outfit that Nyoman's sister wore sometime in the past.

By saying bajunya kakaknya Nyoman tu 'hey (you remember) Nyoman sister's outfit', Ayu introduces an object, the outfit, into the conversation. At the same time, since Ayu refers to a past time, there is a possibility that all participants have seen that outfit in the past. Ayu does not only introduce the outfit but also more likely reminds the other participants about the outfit. That outfit now becomes relevant in their conversation as Ayu tries to induce the other participants to retrieve their memory about the outfit. However, what is the relevant next action may still be unclear here (Cf. Adjacency Pair and Relevance Next Action Schegloff, 2007).

Dewi seems to be lost. In Line 2, Dewi produces an "open class repair initiator" (Drew, 1997) kenapa 'what about (it)', indicating her issue with Ayu's turn (Line 1). Noting that Dewi employs kenapa 'what about (it)' and not yang mana 'which one', or some other repair initiators. Kenapa 'what about (it)' indicates that Dewi does not have any issue in remembering the outfit, she is only confused why all of a sudden Ayu mentions the outfit.

In overlap with Dewi's turn (Line 2), Ayu repeats the word bajunya 'the outfit' (Line 3). In so doing, she can be understood as highlighting that bajunya 'the outfit' is the gist of her turn (Line 1).

Then slightly behind Dewi's turn (Line 2) and Ayu's turn (Line 3), Santi also produces “open class repair initiator" in the form of $e h$ in a rising intonation. Santi's turn, similar to Dewi's (Line 2), can be understood as indicating her confusion on Line 1 . The difference is since Santi employs a nonspecific repair initiator, there is no indication of how much of Ayu's turn has been heard and understood by her. Rising eh can indicate many different things, from trouble in hearing to disbelief.

As a response to the repair initiators (Line 2 and 4), Ayu says dua puluh juta 'twenty-two million (rupiah)' (Line 5, Extract 7). That amount in IDR equal to around USD 2,000 at that time.

It appears that this piece of information in Line5 is vital. It enables the other participants to progress with their conversation (repair initiator, asks for clarification, therefore it cannot be considered as progressing the conversation). In Line 6, Dewi says, pih dia itu nyewa lagi, coba '(You know what), what's more (is that) she (is) even renting, (can you believe it)?'. The interjection pih is a quite common interjection in conversational Indonesian spoken in the area of Denpasar - Bali. This interjection is also common for spoken Balinese variety in that area. Interjection pih carries disbelief, as well as a hint of disgust.

The verb coba 'try' at the end of Line 6, is a kind of construction. It can be construed as the truncated form of a verbal request coba pikir 'go figure'. This construction 'go figure' is a rather common construction in conversational Indonesian spoken in Denpasar - Bali. The construction, as well as its truncated form, carries one's disbelief. The "logic" behind it is that one is utterly taken aback, hence asking the interlocutor to go figure.

Both disbelief and hint of disgust that the interjection pih and the truncated construction coba carry can be understood as Dewi's stance. Though on the surface, Line 6 appears to be giving information that the outfit is rented, it also subtly carries her stance.

Since Line 6 reveals Dewi's stance, she can also be understood as doing an assessment. Nyoman sister's outfit, which is produced in Line 1, can be seen as the assessable. While the underlying stance of disbelief and disgust displayed in Line 6 is Dewi's assessment of the outfit. Noting that it is also possible that the disbelief and hint of disgust are specifically directed towards the piece of information that the outfit is a rented outfit. In any way, the disbelief and hint of disgust are in general directed at the outfit.

Subsequently, Ayu confirms the information that Dewi shared (Line 6). In overlap with the tail end of Dewi's turn, Ayu says ya?a 'yes' (Line 7).

Then, without leaving a considerable gap in between, Santi says ya ampun 'my goodness' (Line 8 ) in response. Her turn carries disbelief. Line 8 is the second assessment in sequence after the object of the assessment is produced (Line 1). Line 8 can be seen as Santi's assessment, both towards the information in Line 6 (that the outfit is rented), as well as the outfit itself.

\section{First speaker produces assessment term after other speakers' assessment term}

The conversation in Extract 8 is taken from a mixedgender four-party conversation at dinnertime. The participants are Sinta, Putu, Ratna, and Teddy. Since Teddy is occupied with his dinner, he does not contribute to the conversation.

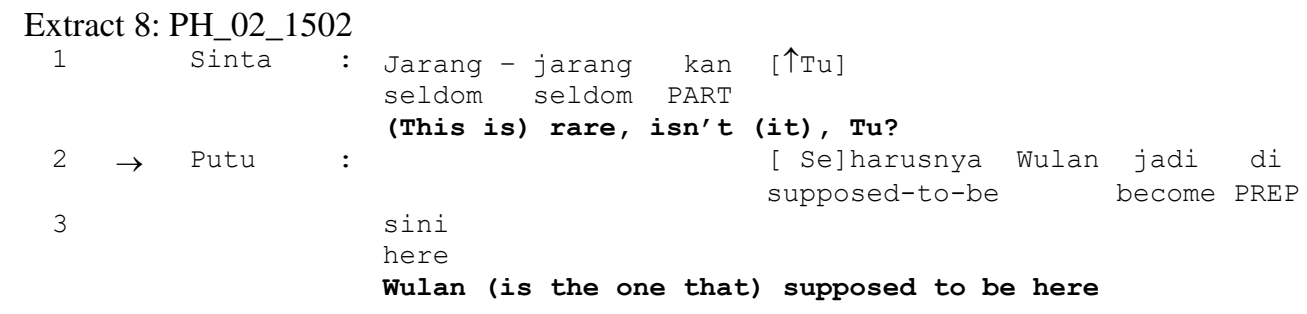




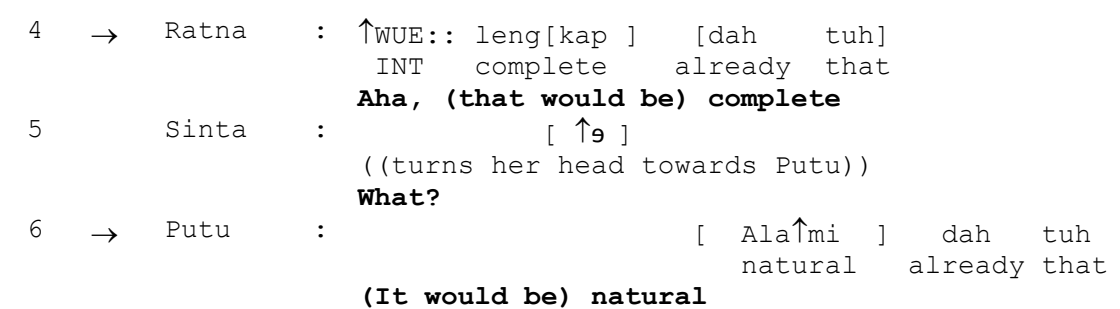

In Line 1, Sinta says, jarang - jarang kan, Tu '(this is) rare, isn't (it), Tu. Tu is the short form of Putu. Consequently, her turn (Line 1) can be understood to be addressed at Putu.

On the day of the data collection, the data collection team bought dinner for the four participants. The four of the participants were all students at that time and they highly appreciated the free dinner.

In Line 2 Putu says, seharusnya Wulan jadi di sini di sini 'Wulan (is the one) that supposed to be here'. He can be understood as suggesting that the more fitting person to be involved in the recording is Wulan.

Then without leaving a considerable gap in between, Ratna says, wue lengkap dah tuh 'aha, that (would be) complete' (Line 4). She can be understood as conveying that Wulan would make their current situation complete. Ratna's turn does not reveal why Wulan's presence will make their current situation complete. Yet, apparently, there is some kind of shared understanding between Putu and Ratna that Wulan would be a fitting person for their current situation.

As we have observed in Extract 7 and Extract 8, assessment in multiparty conversation can be done collaboratively. It appears that shared knowledge (Cf. Takanashi et al., 2006) is the infrastructure that enables collaborative assessment, especially when the object is non-present as in the two extracts.

\section{CONCLUSION}

In the finding and discussion section of this article, we have analyzed 6 extracts, taken from 4 different conversations. In those extracts, we can observe how assessment can be constructed through verbal and non-verbal means, involving a single participant, two, or even more. In all extracts, the assessments consist of two elements: the assessable and assessment.

The assessable, the focal point being assessed in the conversation, can simply be an item (Extract 3, Extract 5, Extract 7), a person (Extract 4), a group of items (Extract 6), or even a condition (Extract 8).

The assessment can be produced through verbal means, e.g. adjective (Extract 3, Extract 5, and Extract 6), phrase (Extract 7 and Extract 8), and interjection (Extract 4 and Extract 7). It can also be displayed through bodily movement or a combination of verbal means and bodily movement as in Extract
4. Each of the assessment carries the speaker's evaluation of and stance towards the assessable.

The analysis of the 5 extracts also shows that assessments are performed as two-step action. The first step is getting the listeners orient to a focal point (i.e. assessable). To achieve listeners' orientation, an assessment may be performed ranging from simply mentioning the assessable (Extract 4, Extract 5, Extract 6, Extract 7, and Extract 8) describing the assessable, to detailing how the assessable operates (Extract 3).

The second step of doing an assessment is presenting or displaying the speaker's assessment towards that focal point or assessable. This can be done by the same speaker (Extract 3) or different speakers (Extract 5, Extract 7, and Extract 8). Assessment can be produced by the speaker who produces the assessable after being prompted by another speaker as in Extract 6. A speaker may reproduce the assessable in the current turn, after an initial production by a prior speaker, when more than one potential assessable is present (Extract 4). Assessment may also be produced in sequence, one speaker after another (Extract 7 and 8).

Additionally, there is one more observation regarding the organization of verbal and non-verbal modalities in an assessment. Non-verbal assessment, as in Extract 4, can be produced earlier than its verbal counterpart. It can be produced almost in overlap with the assessable. Noting that the verbal and nonverbal conveyance in Extract 4 bring a similar stance towards the assessable.

The observation in Extract 4 adds to the multimodal organization of conversational interaction. Verbal and non-verbal modalities are interconnected, yet occupying "different production space", the non-verbal modality may be produced earlier (Cf. Kaukomaa et al., 2013). This observation is also valuable in terms of multimodal "projectability" (Auer, 2005; Hayashi, 2004; Liddicoat, 2004) in conversation.

Lastly, based on the analysis of the extracts, I would like to suggest a new notion: "assessability". This notion becomes relevant especially in the case where the assessable and assessment are not produced by a single participant in a single turn. When a focal point is introduced in a conversation, assessment towards that focal point only becomes relevant. That focal point does not readily become assessable at the point of its production. That focal point has to be assessable in some way or having 
assessability, in order for an assessment to be produced.

In Extract 7, assessment is only produced after a new piece of information regarding the potential assessable is produced. In comparison, in Extract 8, an assessment is readily produced right after the potential assessable is introduced into the conversation. The term assessability encapsulates the intrinsic quality(ies) of a potential assessable and its context(s) of production that enable it to be assessed.

The current study is a preliminary study that looks into the structure of Indonesian conversation, starting from multimodal features of assessment. It is hoped that this study will provide a firm footing for subsequent studies on the structure of Indonesian conversation, from assessment, branching out to various themes.

One possible topic for further study is to tease out the aforementioned notion of assessability. This can be done through gathering and analyzing cases where assessments are produced by two participants or more.

The list of further studies can be said to be endless, one may study the exact placement of facial expression in delivering assessment, assessment in second and third position, assessment in different contexts, etc. The main point is that more studies should be done on naturally occurring conversational Indonesian, simply because it is the real day to day language of the Indonesian people.

\section{REFERENCES}

Antaki, C. (2002). "Lovely": Turn-initial high-grade assessments in telephone closings. Discourse Studies, 4(1), 5-23. https://doi.org/10.1177/1461445602004001010 1

Antaki, C., \& O'Reilly, M. (2013). Either/or questions in child psychiatric assessments: The effect of the seriousness and order of the alternatives. Discourse Studies, 16(3), 327345.

Auer, P. (2005). Projection in interaction and projection in grammar. Text-Interdisciplinary Journal for the Study of Discourse, 25(1), 736.

Benwell, B., \& Rhys, C. S. (2018). Negotiating relevance in pre-operative assessments. Social Science \& Medicine, 200, 218-226. https://doi.org/10.1016/j.socscimed.2018.01.03 4

Day, D., \& Kristiansen, E. D. (2018).

Demonstrating and claiming competence in language: Doing being better or worse than others. Journal of Pragmatics, 126, 90-105. https://doi.org/10.1016/j.pragma.2018.01.003

Djenar, D. N. (2006). Patterns and variation of address terms in colloquial Indonesian. Australian Review of Applied Linguistics,
29(2).

http://www.nla.gov.au/openpublish/index.php/ aral/article/view/1930

Djenar, D. N. (2013). Adolescent social media interaction and authorial stance in Indonesian teen fiction. Wacana, 15(1), 165-179. https://doi.org/10.17510/wjhi.v15i1.109

Djenar, D. N., \& Ewing, M. C. (2015). Language varieties and youthful involvement in Indonesian fiction. Language and Literature, 24(2), 108-128. https://doi.org/10.1177/0963947015573387

Drew, P. (1997). 'Open' class repair initiators in response to sequential sources of troubles in conversation. Journal of Pragmatics, 28(1), 69101. https://doi.org/10.1016/S03782166(97)89759-7

EMCA bibliography database. (n.d.). Retrieved July 16, 2019, from http://emcawiki.net/bibtex/browser.php?frames et\&bib=emca.bib

Ewing, M. C. (2005). Colloquial Indonesian. In K. A. Adelaar \& N. Himmelmann (Eds.), The Austronesian languages of Asia and Madagascar (pp.227-258). Routledge.

Fasulo, A., \& Monzoni, C. (2009). Assessing mutable objects: A multimodal analysis. Research on Language \& Social Interaction, 42(4), 362-376. https://doi.org/10.1080/08351810903296481

Fields, P., \& Fields, P. (2010). Papuan colloquial Indonesian. SIL Electronic Working Papers 2010-005. Sl: sn iii, 18 pages. http://www. sil. org/silewp/abstract. asp. http://12.177.127.6/SILEWP/2010/silewp2010 -005.pdf

Filipi, A., \& Wales, R. (2010). The organization of assessments produced by children and adults in task based talk. Journal of Pragmatics, 42(11), 3114-3129. https://doi.org/10.1016/j.pragma.2010.04.013

Gil, D. (2008). Intonation and thematic roles in Riau Indonesian. In Topic and Focus. Studies in Linguistics and Philosophy (Vol. 82, pp. 41-68). Springer, Dordrecht. https://link.springer.com/chapter/10.1007/978-14020-4796-1_3

Goodwin, C. (1986). Between and within: Alternative sequential treatments of continuers and assessments. Human Studies, 9(2), 205-217. https://doi.org/10.1007/BF00148127

Goodwin, C., \& Goodwin, M. H. (1987). Concurrent operations on talk: Notes on the interactive organization of assesments. IPrA Papers in Pragmatics, 1(1), 1-52. https://doi.org/10.1075/iprapip.1.1.01goo

Goodwin, C., \& Goodwin, M. H. (1992). Assessments and the construction of context. In A. Duranti \& C. Goodwin (Eds.), Rethinking context: Language as an interactive phenomenon (Vol. 11, p. 147). Cambridge University Press. 
Goodwin, M. H. (2007). Participation and embodied action in preadolescent girls' assessment activity. Research on Language and Social Interaction, 40(4), 353-375. https://doi.org/10.1080/08351810701471344

Hayano, K. (2011). Claiming epistemic primacy: Yomarked assessments in Japanese. In T. Stivers, L. Mondada, \& J. Steensig (Eds.), The Morality of Knowledge in Conversation (pp. 58-81). Cambridge University Press.

Hayashi, M. (2004). Projection and grammar: Notes on the 'action-projecting' use of the distal demonstrative are in Japanese. Journal of Pragmatics, 36(8), 1337-1374. https://doi.org/10.1016/j.pragma.2004.05.006

Heritage, J. (2002). Oh-prefaced responses to assessments: A method of modifying agreement/disagreement. In C. E. Ford, B. A. Fox, \& S. A. Thompson (Eds.), The Language of Turn and Sequence (pp. 196-224). Oxford.

Heritage, J. (2012). Epistemics in Action: Action Formation and Territories of Knowledge. Research on Language \& Social Interaction, 45(1). https://doi.org/10.1080/08351813.2012.646684

Heritage, J., \& Raymond, G. (2005). The terms of agreement: Indexing epistemic authority and subordination in talk-in-interaction. Social Psychology Quarterly, 68(1), 15-38. https://doi.org/10.1177\%2F01902725050680010 3

Ivaldi, A. (2018). Explicit versus performative assessments in music pedagogical interactions. British Journal of Music Education, 36(1), 6986. https://doi.org/10.1017/S0265051717000262

Jones, C. M. (1997). "That's a good sign": Encouraging assessments as a form of social support in medically related encounters. Health Communication, 9(2), 119-153. https://doi.org/10.1207/s15327027hc0902_2

Kaukomaa, T., Peräkylä, A., \& Ruusuvuori, J. (2013). Turn-opening smiles: Facial expression constructing emotional transition in conversation. Journal of Pragmatics, 55, 21-42. https://doi.org/10.1016/j.pragma.2013.05.006

Kiyimba, N., O’Reilly, M., \& Lester, J. N. (2018). Agenda setting with children using the 'three wishes' technique. Journal of Child Health Care, 22(3), 419-432. https://doi.org/10.1177/1367493518762487

Lee, S.-H. (2013). Response design in conversation. In J. Sidnell \& T. Stivers (Eds.), The handbook of conversation analysis (pp. 415-432). WileyBlackwell.

Lerner, G. H. (1996). On the "semi-permeable" character of grammatical units in conversation: Conditional entry into the turn space of another speaker. In E. Ochs, E. Schegloff, \& S. A. Thompson (Eds.), Interaction and Grammar (pp. 238-276). Cambridge University Press.

Levinson, S. C. (2013). Action formation and ascription. In J. Sidnell \& T. Stivers (Eds.),
The handbook of conversation analysis (pp. 103-130). Wiley-Blackwell.

Liddicoat, A. J. (2004). The projectability of turn constructional units and the role of prediction in listening. Discourse Studies, 6(4), 449-469. https://doi.org/10.1177/1461445604046589

Lindstrom, A., \& Sorjonen, M.-L. (2013). Affiliation in Conversation. In J. Sidnell, \& T. Stivers (Eds.), The handbook of conversation analysis (pp. 350369). Blackwell Publishing Ltd.

Ochs, E., Schegloff, E. A., \& Thompson, S. A. (1996). Interaction and grammar. Cambridge University Press.

Oktarini, K. R. D. (2017). Flirtatious sequence in Indonesian: A conversation analytic and membership categorization analytic approach [Unpublished doctoral dissertation] Nanyang Technological University, Singapor.

Oktarini, K. R. D. (2019). Assessment sequence in gossiping in Indonesian conversation: A conversation analysis study. Proceedings of the 2019 International Conference on the Austronesian and Papuan Worlds (ICAPaW 2019), 94-101.

Oshima, S. (2018).. Embodiment of activity progress. In A. Deppermann \& J. Streeck (Eds.), Time in embodied interaction: Synchronicity and sequentiality of multimodal resources (pp. 261-292). John Benjamins Publishing Company.

Park, I. (2018). Reported thought as (hypothetical) assessment. Journal of Pragmatics, 129, 1-12. https://doi.org/10.1016/j.pragma.2018.03.003

Pillet-Shore, D. (2012). The problems with praise in parent-teacher interaction. Communication Monographs, 79(2), 181-204. https://doi.org/10.1080/03637751.2012.672998

Pomerantz, A. (1984). Agreeing and disagreeing with assessments: Some features of preferred/dispreferred turn shapes. In J. M. Atkinson \& J. Heritage (Eds.), Structures of social action (pp. 57-95). Press Syndicate of the University of Cambridge.

Pomerantz, A. (1975). Second assessments: A study of some features of agreements/disagreements. University of California, Irvine.

Pomerantz, A., \& Heritage, J. (2013). Preference. In J. Sidnell \& T. Stivers (Eds.), The handbook of conversation analysis (pp. 210-228). John Wiley \& Sons, Ltd.

Raymond, G., \& Heritage, J. (2006). The epistemics of social relations: Owning grandchildren. Language in Society, 35(05), 677-705. https://doi.org/10.1017/S0047404506060325

Ruusuvuori, J., \& Peräkylä, A. (2009). Facial and verbal expressions in assessing stories and topics. Research on Language \& Social Interaction, 42(4), 377-394. https://doi.org/10.1080/08351810903296499 
Sacks, H., Schegloff, E. A., \& Jefferson, G. (1974). A simplest systematics for the organization of turn-taking for conversation. Language, 50(4), 696-735. https://doi.org/10.2307/412243

Schegloff, E. A. (2007). Sequence organization in interaction, Volume 1: A primer in conversation analysis. Cambridge University Press.

Schegloff, E. A. (2013). Ten operations in selfinitiated, same-turn repair. In M. Hayashi, G. Raymond, \& J. Sidnell (Eds.), Conversational repair and human understanding (pp. 41-70). Cambridge University Press.

Schenkein, J. (1978). Studies in the organization of conversational interaction. Academic Press.

Seuren, L. M. (2018). Assessing answers: Action ascription in third position. Research on Language and Social Interaction, 51(1), 33-51. https://doi.org/10.1080/08351813.2018.1413890

Sidnell, J. (2010). Conversation analysis: An introduction. John Wiley and Sons.

Sneddon, J. N. (2003). Diglossia in Indonesian. Bijdragen Tot de Taal-, Land-En Volkenkunde, 159(4), 519-549.

https://brill.com/downloadpdf/journals/bki/159 /4/article-p519_4.pdf

Sneddon, J. N. (2006). Colloquial Jakartan Indonesian. Pacific Linguistics, Research School of Pacific and Asian Studies, The Australian National University.

Stoel, R. (2000). Discourse particle in Manado Malay. Linguistics in the Netherlands, 17(1), 185-198. https://doi.org/10.1075/avt.17.18sto

Takanashi, K., Fujimoto, E., Kono, Y., Takeuchi, K., \& Isahara, H. (2006). Detection of assessment patterns in ordinary triadic conversation. In T. Washio, A. Sakurai, K. Nakajima, H. Takeda, S. Tojo, \& M. Yokoo
(Eds.), New frontiers in artificial intelligence (Vol. 4012, pp. 389-400). Springer Berlin Heidelberg. http://www.springerlink.com.ezlibproxy1.ntu.e du.sg/content/mr4x023m05862853/

Tanaka, H. (2016). Lexico-grammatical structures of agreements with assessments in English conversation: From a Japanese perspective. Journal of Pragmatics, 100, 8-24. https://doi.org/10.1016/j.pragma.2015.11.006

ten Have, P. (2007). Doing conversation analysis: A practical guide. SAGE Publications Ltd.

Tolins, J. (2013). Assessment and direction through nonlexical vocalizations in music instruction. Research on Language \& Social Interaction, 46(1), 47-64. https://doi.org/10.1080/08351813.2013.753721

Williams, N. (2009). Toward a linguistic anthropological account of deixis in interaction: Ini and Itu in Indonesian conversation. Colorado Research in Linguistics, 22(1). https://doi.org/10.25810/0ghq-wk77

Wouk, F. (1998). Solidarity in Indonesian conversation: The discourse marker kan. Multilingua - Journal of Cross-Cultural and Interlanguage Communication, 17(4), 379406. https://doi.org/10.1515/mult.1998.17.4.379

Wouk, F. (2001). Solidarity in Indonesian conversation: The discourse marker ya. Journal of Pragmatics, 33(2), 171-191. https://doi.org/10.1016/S0378-2166(99)001393

Wouk, F. (2005). The syntax of repair in Indonesian. Discourse Studies, 7(2), 237-258. https://doi.org/10.1177/1461445605050368 